\title{
Leafcutter Ants in Southern Amazon Forests, Brazil
}

\author{
Odair Carlos Zanardi ${ }^{1}$, Vânia Beatriz Cipriani ${ }^{2} \&$ Juliana Garlet $^{1}$ \\ ${ }^{1}$ Department of Forestry Engineering, Faculty of Biological and Agrarian Sciences, University of the State of \\ Mato Grosso, Brazil \\ ${ }^{2}$ Instituto Nacional de Pesquisas da Amazônia, Brazil \\ Correspondence: Department of Forestry Engineering, Faculty of Biological and Agrarian Sciences, University \\ of the State of Mato Grosso, Brazil. E-mail: julianagarlet@unemat.br
}

Received: July 9, $2018 \quad$ Accepted: August 16, $2018 \quad$ Online Published: October 15, 2018

doi:10.5539/jas.v10n11p242 URL: https://doi.org/10.5539/jas.v10n11p242

\begin{abstract}
This study aims to identify the species of leafcutter ants, the infestation rate and the spatial distribution of anthills in forest plantations in Alta Floresta-MT. The samples were collected in five plots, with I and II being a Eucalyptus urophylla $\times$ Eucalyptus grandis hybrid plantation, III a consortium of Brazil nuts (Bertholletia excelsa) and rubber tree (Hevea brasiliensis), IV and V plots of Tectona grandis. The size of the anthills were measured, obtaining the area in square meters of loose ground, were classified into size classes I: $\leq 1 \mathrm{~m}^{2}$; class II: 1.1 to $2.9 \mathrm{~m}^{2}$; class III: 3 to $8.9 \mathrm{~m}^{2}$; class IV: 9 to $25 \mathrm{~m}^{2}$ e class V: $>25 \mathrm{~m}^{2}$. To calculate dispersion, the Dispersion (DI) and Morisita Index (I6) were used. Only one species was observed in all plots (Atta sexdens rubropilosa Forel, 1908). 838 nests were mapped in the five sampled plots, the total average density of anthills found in the plots was 26 anthills/ha. The average total area of loose soil occupied by anthills was $590.05 \mathrm{~m}^{2}$, the distribution of anthills between size classes showed $86.87 \%$ disproportion with the anthills in class I. The distribution of the anthills in the five plots that were evaluated were of the aggregate type, following the Morisita Index and the Dispersion index.
\end{abstract}

Keywords: Atta sexdens rubropilosa, forest entomology, reforestation, Mato Grosso

\section{Introduction}

With the growing demand for timber and the decrease in the exploitation of native forests, forest plantations have become an important source of wood products. According to FAMATO (2013) in recent years, native logging showed a drop in the production of charcoal, firewood and roundwood in the country of $47 \%, 14 \%$ and $14 \%$, respectively. In contrast, production in forestry showed growth in all modes, and $8 \%$ for charcoal, $32 \%$ for firewood and $20 \%$ for roundwood, the latter being divided between pulp and paper and other uses. The fact is that forest plantations are a renewable source of raw material with rapid growth, and each year its cultivation is increased in Brazil and in the State of Mato Grosso (FAMATO, 2013).

According to Barros (2015), forestry is a science that seeks natural and artificial ways of restoration and improvement of forest products to meet market requirements. Consequently, with the increase in forested areas, the increase of entomological problems is also observed, and even today, leafcutter ants are considered the main group of forest pests.

Leafcutter ants (Hymenoptera: Formicidae) belong to the genera Atta (Saúvas) and Acromyrmex (Quenquéns), known for cultivating fungi in gardens, with which it has a symbiotic relationship by providing fresh plant material (Brandão, Mayhé-Nunes, \& Sanhudo, 2011). This group has 16 genera and over 254 species and have limited occurrence in the Americas (Della Lucia, Gandra, \& Guedes, 2014).

Leafcutter ants, Atta sp. and Acromyrmex sp., are considered the main pests of reforestation in Brazil due to the high number of colonies per area, the large number of individuals per colony, its great voracity, by its constant presence and wide distribution (Costa, D'avila, \& Cantarelli, 2014). Leafcutter ants stand out for their potential for damage, and severe and repeated attacks that lead to defoliation and mortality of seedlings and even mature trees, if not properly controlled. 
According to Costa et al. (2014), for the control of this insect pest, the most used method is the granulated bait based on fipronil and sulfluramide. They are widely used due to their practicality; however, inadequate application can cause major problems, such as resistance to this active ingredient in the bait.

Considering that the north of Mato Grosso shows increasing forest areas, mainly in planting Tectona grandis and Eucalyptus spp., the knowledge of leafcutter species associated with these crops is essential, especially for management measures and control of this important group of forest pests.

This work aims to identify the species of leafcutter ants, the infestation rate and the spatial distribution of anthills in forest plantations in the southern amazon in Alta Floresta, Mato Grosso, Brasil. In this context, the following hypotheses were tested: (i) There is a predominance of Atta genus in the region and (ii) In eucalyptus plantations there is a greater occurrence of leaf-cutting ants.

\section{Material and Methods}

The survey realized in this study was conducted in five plots from four forest species. Two plots (I and II) being a Eucalyptus urophylla $\times$ Eucalyptus grandis hybrid plantation, located at the Brasil Tropical Pisos company, located on highway MT 208, $15 \mathrm{~km}$ from the city of Alta Floresta-MT. Plot III belongs to a forest planted in consortium of Bertholletia excelsa (Brazil nut) and Hevea brasiliensis (rubber tree), located on highway MT 208, $10 \mathrm{~km}$ from Alta Floresta, on the Dois irmãos farm. Plots IV and V are Tectona grandis (Teak), belonging to IDC farm, located on highway MT 010, with a distance of 27, $22 \mathrm{~km}$ from Alta Floresta.

The Municipality of Alta Floresta is located in the northern state of Mato Grosso, with an altitude of $283 \mathrm{~m}$. The climate is Am type with two distinct seasons, rainy summer and dry winter, the annual average temperature is around $26{ }^{\circ} \mathrm{C}$, and the average annual rainfall is in the $2800-3100 \mathrm{~mm}$ range, according to the Köppen classification for Brazil (Alvares, Stape, Sentelhas, Gonçalves, \& Sparovek, 2014).

The I and II plots, planted with hybrid H13 Eucalyptus urophylla $\times$ Eucalyptus grandis, are six years of age, and have a spacing of $3 \times 3 \mathrm{~m}$ with an area of 12.21 ha, divided into two plots with the first being 6.45 ha and the second being 5.76 ha. The consortium of Bertholletia excelsa and Hevea brasiliensis (plot III) are 20 years old with $20 \mathrm{~m}$ spacing between rows and $5 \mathrm{~m}$ between trees, with a total area of 13.05 ha. The IV and V plots, planted with Tectona grandis, are 14 years old, spaced at $3 \times 2.2 \mathrm{~m}$ and comprise a planting area of 14.65 ha and 7.52 respectively.

To analyze the distribution of anthills and identify the species of leafcutter ants, a census of all the ant colonies present in the evaluated areas was conducted. After identifying each hive, the apparent dimensions of these were obtained (greater length $\times$ greater width). The anthills were georeferenced using GPS, and samples were collected for the identification of ants (a soldier in a worker).

For size classification of anthills, the length of the major axis is multiplied by the larger width, and thus the anthill area in square meters was obtained. The size classes were established according to Caldeira, Zanetti, Moraes, and Zanuncio (2005): class I: $\leq 1 \mathrm{~m}^{2}$; class II: 1.1 to $2.9 \mathrm{~m}^{2}$; class III: 3 to $8.9 \mathrm{~m}^{2}$; class IV: 9 to $25 \mathrm{~m}^{2}$ and class V: $>25 \mathrm{~m}^{2}$.

To determine the spatial distribution of anthills within the plots, $40 \times 40 \mathrm{~m}$ plots were established, ie $1600 \mathrm{~m}^{2}$ and evaluated 36 sections in plot I, 32 in plot II, 72 in plot III, 84 in plot IV and 46 in plot V, totaling 270 plots. The total number of sections/plots, the total number of anthills/plot, the mean and variance of the total number of anthills were used to calculate the spatial distribution per plot using the dispersion index (DI). According to Davis (1993), the index has the following spatial distribution criteria: $\mathrm{I}=1$, random distribution; I $>1$, aggregated distribution; $\mathrm{I}<1$, regular distribution.

The dispersion index (ID): was obtained by Equation 1:

$$
\mathrm{ID}=\mathrm{S}^{2} / \mathrm{X}
$$

Where: $S^{2}=$ sample variance, $X=$ average anthill/plots number.

Along with the Dispersion Index to determine the spatial distribution of ant colonies, the Morisita index (I6) was also calculated (Morisita 1959). This index is widely used, because according to Barros and Machado (1984), it is little influenced by the size of the sample unit, and also has the advantage of being relatively independent of the average and the number of samples.

The Morisita index $(I \sigma)$ : was determined by Equation 2:

$$
I \sigma=\mathrm{N}\left[\left(\sum \mathrm{x}^{2}-\sum \mathrm{x}\right) /\left(\left(\sum \mathrm{x}\right)^{2}-\sum \mathrm{x}\right)\right]
$$


Where: $\mathrm{N}=$ Number of sample units, $\Sigma \mathrm{x}=$ Sum of the individuals present in the sample units, $\Sigma \mathrm{x}^{2}=$ Squared sum of individuals present in the sample units. Thus, I $\sigma=1$, the distribution is random; When I $\sigma>1$, distribution is aggregated and when Iб $<1$ indicates a regular distribution (Morisita, 1962).

\section{Results}

838 anthills were found in the five plots assessed, totaling 47.43 anthills/ha, but only one species of leafcutter ant was found and identified, Atta sexdens rubropilosa Forel, 1908, better known as lemon ants.

The total average density of leafcutter ants found in the plots was 26 anthills/ha, with a range from 0.89 to 60.93 anthills/ha. The average total area of loose soil was $590.05 \mathrm{~m}^{2}$, ranging from 148.5 to $962.5 \mathrm{~m}^{2}$, according to Table 1.

Table 1. Total area of loose soil $\left(\mathrm{m}^{2} / \mathrm{ha}\right)$ and total density of leafcutter ants $(\mathrm{n} / \mathrm{ha})$ in plots of forest species

\begin{tabular}{lllllllll}
\hline Plot & \multicolumn{7}{c}{ Leafcutter ant soil area $\left(\mathrm{m}^{2} /\right.$ ha) by size class $\left(\mathrm{m}^{2}\right)^{*}$} \\
\hline $\mathrm{N}^{\mathrm{o}}$ & Area (ha) & Class I & Class II & Class III & Class IV & Class V & Total & Total density $(\mathrm{n} / \mathrm{ha})$ \\
\hline $\mathrm{I}$ & 6.45 & 302.00 & 4.00 & 11.00 & 144.00 & 297.00 & 758.00 & 50.08 \\
$\mathrm{II}$ & 5.76 & 318.00 & 17.00 & 63.75 & 104.00 & 459.75 & 962.50 & 60.93 \\
$\mathrm{III}$ & 13.05 & 89.00 & 3.00 & 49.00 & 267.50 & 481.75 & 890.25 & 68.22 \\
$\mathrm{IV}$ & 14.65 & 6.00 & 0.00 & 4.00 & 20.00 & 161.00 & 191.00 & 13.08 \\
$\mathrm{~V}$ & 7.52 & 13.00 & 0.00 & 16.00 & 70.50 & 49.00 & 148.50 & 19.75 \\
\hline Average & 9.48 & 145.6 & 4.8 & 28.75 & 121.20 & 277.10 & 590.05 & 42.41 \\
\hline
\end{tabular}

Note. The I and II plot planted with Eucalyptus urophylla $\times$ Eucalyptus grandis hybrid, III Bertholletia excelsa $\mathrm{e}$ Hevea brasiliensis consortium, IV and V with Tectona grandis. * Classe I $\left(<1.0 \mathrm{~m}^{2}\right)$, II $\left(1.0\right.$ to $\left.2.9 \mathrm{~m}^{2}\right)$, III $(3.0$ to $\left.8.9 \mathrm{~m}^{2}\right)$, IV $\left(9.0\right.$ to $\left.25.0 \mathrm{~m}^{2}\right)$ andV (>25.0 $\mathrm{m}^{2}$ of loose soil).

The distribution of anthills between the size classes in this study proved to be disproportionate, with $86.87 \%$ of anthills in class I, as can be seen in Figure 1.

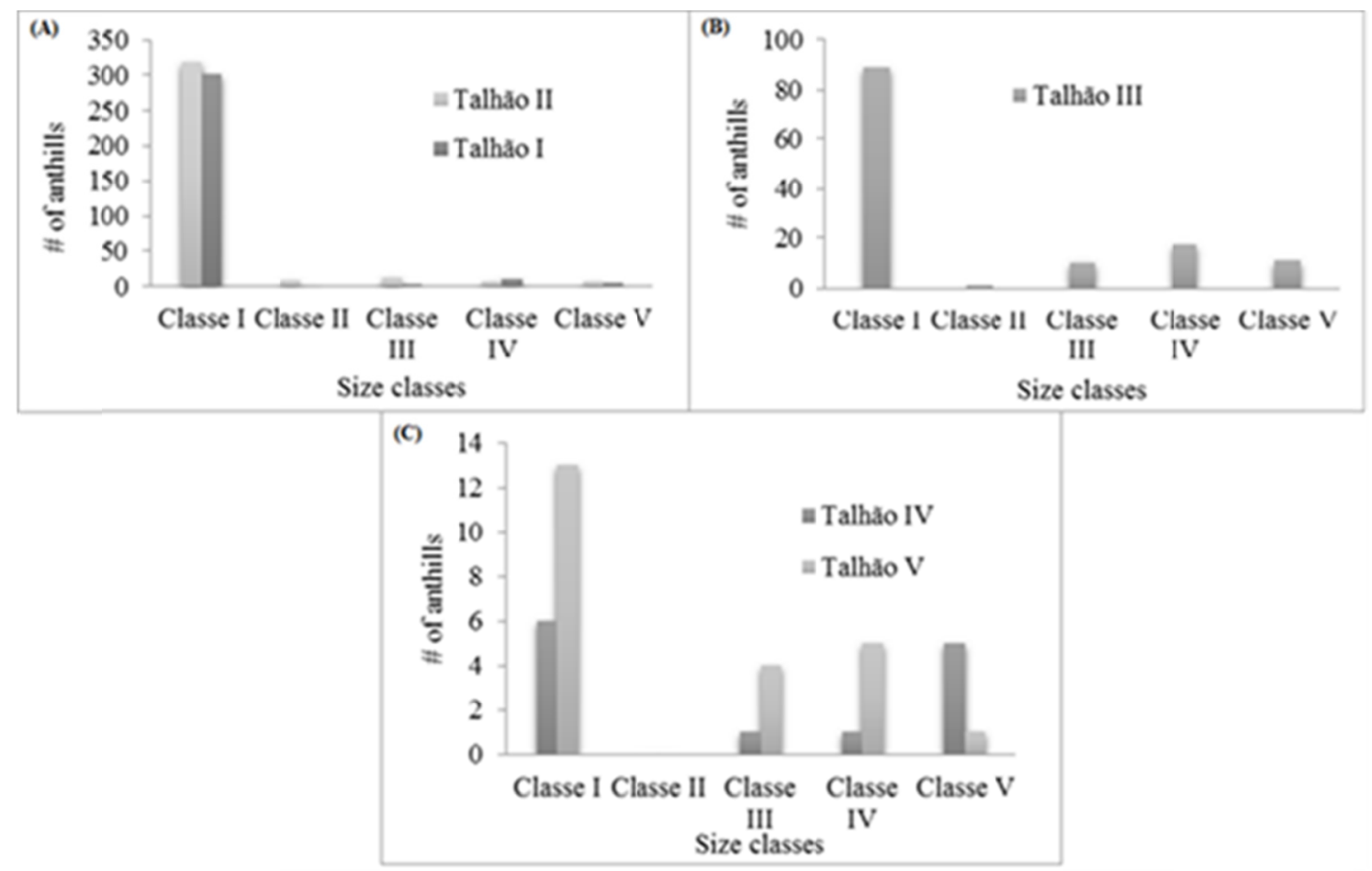

Figure 1. Number of anthills found in each size class of forest plots of different species 
According to the data presented in Figure 1, Class V showed a low concentration of anthills, but most of the average area of loose soil was $590.05 \mathrm{~m}^{2} /$ ha, unlike classes II and III with low loose soil content compared with the other classes. Plots I and II, with Eucalyptus forest, showed a significant number of anthills/ha, the first plot having 50.7 anthills/ha, the second plot having 60.9 anthills/ha.

Most anthills identified in the study areas were found in Class I with 302 anthills in the first plot and 318 in the second, as shown in Figure 1. However, the other classes presented few anthills in the first and second plot, class II with 2 and 8 anthills, class III with 4 and 12 anthills, class IV with 11 and 7 anthills and finally class V with 6 anthills.

The consortium between Brazil nuts and Rubber trees (plot III) had 128 anthills, well below the number found in plots I and II, the average was 15.1 anthills/ha. Although with the greatest prevalence occurring in class I with $67 \%$ of anthills, class $\mathrm{V}$ reaching the highest values ( $8.5 \%$ of anthills), totaling an average of $43.79 \mathrm{~m}^{2}$ of loose soil occupied by anthills.

Plots IV and V, with a Tectona grandis plantation, showed differences in the anthill distribution patterns by classes when compared to other plots, which were not found in class II anthills. Caldeira et al. (2005) in studies in Minas Gerais evaluating spatial distribution of anthills, also noted that the last class had low percentage of leafcutter anthills but accounted for most of the average area of loose soil of $95.2 \mathrm{~m}^{2} / \mathrm{ha}$.

The distribution of nests in the five plots evaluated was of the aggregate type as shown in Table 2.

Table 2. Determination of spatial distribution of anthills using the Morisita index (I6) and dispersion index (DI) for plots with different forest species

\begin{tabular}{llllll}
\hline Plot & Area (ha) & \# of sections & \# of anthills & Morisita Index (Iб) & Dispersion Index (ID) \\
\hline I & 6.4 & 36 & 351 & $1.24^{\mathrm{Ag}}$ & $3.25^{\mathrm{Ag}}$ \\
II & 5.76 & 32 & 323 & $1.21^{\mathrm{Ag}}$ & $3.11^{\mathrm{Ag}}$ \\
III & 13.05 & 72 & 128 & $1.66^{\mathrm{Ag}}$ & $2.14^{\mathrm{Ag}}$ \\
IV & 14.65 & 84 & 13 & $3.23^{\mathrm{Ag}}$ & $1.31^{\mathrm{Ag}}$ \\
V & 7.52 & 46 & 26 & $2.9^{\mathrm{Ag}}$ & $1.89^{\mathrm{Ag}}$ \\
\hline Average & 9.49 & 270 & 168.20 & $2.048^{\mathrm{Ag}}$ & $2.34^{-3}$
\end{tabular}

Note. І $\sigma=1$, the distribution is random; When Iб $>1$, distribution is of the aggregate type and when І $6<1$ indicates a regular distribution (Morisita 1962). For the dispersion index, ID $<1$, regular dispersion, ID $=1$, random dispersion, ID $>1$, aggregated dispersion.

As noted in Table 2, there was a predominance of aggregate distribution of Atta sexdens rubropilosa anthills. For there to be an aggregate pattern in the plots, some factors influence the distribution of anthills in the areas, the high presence of grasses observed in all evaluated plots may be hindering the formation of anthills.

\section{Discussion}

In this study the hypothesis of the prevalence of the Atta genus in the region was confirmed, demonstrating further that sauva lemon (Atta sexdens) is the species with the highest occurrence. According to Souza, Anjos, Cordeiro and Mourão (2009) Atta sexdens, is a species of leafcutter ant of great economic importance for forage plants of forest crops. The lemon ant has been registered in ten Brazilian states, cutting leaves in more than 30 species of trees.

Silva and Ukan (2015), evaluating spatial distribution of leafcutter ants in a forest plantation of Eucalyptus benthamii in the municipality of Irati - PR, found during the survey 51 anthills in activity in the area of 1 ha. Of these, 35 were identified as the Acromyrmex genus.

These data confirm the presence of these insects in the reforestation of various regions, its kind of diversity being associated with conditions of places of occurrence. In this study for example, the presence of the Acromyrmex genus was not found in any of the five plots evaluated. Regarding the occurrence of ants, planting with eucalyptus had a large number of ant hills per hectare. However, it was similar to the Bertholletia excelsa e Hevea brasiliensis consortium, rejecting the hypothesis of eucalyptus plantations to present a higher occurrence of ants in this region.

Lasmar, Zanetti, Santos, and Fernandes (2012) evaluating the use of geostatistics to determine the distribution rate and spatial infestation of leafcutter ants nests in eucalyptus plantations in the Paraopeba region, Minas 
Gerais, found that the number of Atta spp. anthills found in eucalyptus plantations was $190.3 /$ ha and the loose soil area was $401 \mathrm{~m}^{2} / \mathrm{ha}$.

In a plantation with 10 Eucalyptus urophylla crops in the region of Montes Claros-Minas Gerais, there was loose soil area of $33.8 \mathrm{~m}^{2} /$ ha and total density of 1.5 anthills/ha for Atta sexdens rubropilosa, probably the lowest density due to the fact that the plots used were controlled in the previous year (Zanuncio, Lopes, Zanetti, \& Couto, 2002). The high anthill density values, and loose soil observed in this study were possibly caused by a lack of control in the plots, or ineffective control.

Zanetti, Jaffé, Vilela, Zanuncio, and Leite (2000) observed similar behavior with a density of 412.83 anthills in Eucalyptus spp. forests, in João Pinheiro, Minas Gerais, where class I presented $75.5 \%$ of anthills found and class V, only $2.4 \%$. Silva and Ukan (2015), identifying the species of leafcutter ants in a forest plantation of Eucalyptus benthamii in the city of Irati/PR, noted the predominance of anthills of classes II and III, or anthills that were already installed in the area for some time.

The results found by Silva and Ukan (2015) coincide with those found by Nickele, Reis Filho, Oliveira \& Iede, (2009), evaluating the spatial distribution of Acromyrmex crassispinus (forel) in Pinus taeda plantations in an area with planting more than three years old where the predominance of anthills of classes II and III occurred. Only two anthills were found in the area possessed dimensions apparently larger than $1 \mathrm{~m}^{2}$.

The age of adult Atta sexdens nests can be estimated by the area of loose soil of the same, since Atta sexdens rubropilosa anthills presented about $10 \mathrm{~m}^{2}$ of loose soil area after two years of its establishment (Hernández et al., 1999). In this plot (III), as previously mentioned, control was not performed, because there are many adult anthills over three years of age. But remained as the previous ones, with the highest concentration of anthills in class I, plot IV showed a high number of anthills in class V.

This size distribution behavior of leafcutter anthills seems to be the normal pattern for this genus, in which a large number of winged ants is generated and scattered over long distances by the wind, to vacant places for colonization. Leafcutter ants reduce the productivity of wood between 0.04 to $0.13 \mathrm{~m}^{3}$ ha ${ }^{-1}$ for each $\mathrm{m}^{2}$ of loose soil area caused by anthills, depending on the site cultivated with eucalyptus in Atlantic Forest areas, which results in an economic damage level between 13.4 to $39.2 \mathrm{~m}^{2} \mathrm{ha}^{-1}$ (Zanetti, Souza, \& Calegario, 2011). Hernandez and Jaffe (1995), concluded that densities above 30 anthills/ha of Atta laevigata in Pinus caribae in the Venezuelan Savannah can reduce wood production by more than $50 \%$.

Zanetti, Zanuncio, Mayhé-Nunes, Medeiros, and Souza-Silva (2003) found that anthill densities with an area equal to $2.76 \mathrm{~m}^{2} / \mathrm{ha}$ of loose soil reduce by $0.87 \%$ the volume of Eucalyptus spp. wood in commercial plantations in the Cerrado. This resulted in an estimated economic damage of between 7.02 and $34.86 \mathrm{~m}^{2} \mathrm{ha}^{-1}$.

The distribution of aggregate type anthills was observed in this study. According to Roglin, Sousa, Pinto, Koehler and Ferronato (2013), the distribution of aggregate may result from the distribution of microhabitats for mutualistic interactions or mother colony ramifications because the heterogeneity of the environment influences it, in order for the aggregation of nests to occur.The aggregate distribution was also observed in surveys conducted by Ramos, Forti, Andrade, Noronha, and Silva Camargo (2008) in colonies of Atta sexdens rubropilosa and Atta laevigata in Eucalyptus plantations. However, they differ from observations made by Nickele, Oliveira, Reis Filho, Iede, and Ribeiro Rodrigo (2010), which found random distribution for Acromyrmex spp. anthills in Pinus plantations.

The aggregate spatial distribution for leafcutter ants of the Atta genus was reported by Lasmar et al. (2012) evaluated the use of geostatistics to determine the spatial rate, distribution and infestation of leafcutter anthills in Eucalyptus spp. where the spatial distribution of the same was aggregated.

In all plots evaluated, a tendency where the highest concentration of anthills were found near the edges of the plots was observed. A fact confirmed by Ramos et al. (2008) in Eucalyptus sp. forests in the state of Santa Catarina. Zanuncio et al. (2002) studied the spatial distribution of Atta sexdens rubropilosa anthills in Eucalyptus urophylla plantations and found that $29.3 \%$ of anthills were located in the first 10 meters from the edge of the plots.

Thus, in this study we observed: in the sampled areas, the predominance of only one species of leafcutter ants was observed: Atta sexdens rubropilosa. Most anthills found presented $1 \mathrm{~m}^{2}$ of loose soil, but the total of loose soil found in the plots was $2950.25 \mathrm{~m}^{2}$ and an average of 42.41 anthills/ha. The Dispersion Index (ID) and Morisita Index (Iб) showed an aggregated spatial distribution of Atta sexdens rubropilosa for all flots evaluated. 


\section{References}

Alvares, C. A., Stape, J. L., Sentelhas, P. C., Gonçalves, J. L. M., \& Sparovek, G. (2014). Köppen’s climate classification map for Brazil. Meteorologische Zeitschrift, 22, 711-728. https://doi.org/10.1127/ 0941-2948/2013/0507

Barros, T. D. (2015). Árvore do conhecimento: Silvicultura. AGEITEC (Agência Embrapa de Informação Tecnológica). Retrieved from http://www.agencia.cnptia.embrapa.br/gestor

Barros, P. L. C., \& Machado, S. A. (1984). Aplicação de índices de dispersão em espécies de florestas tropicais da Amazônia brasileira. Curitiba: FUPEF, Série Científica I.

Brandão, C. R. F., Mayhé-Nunes, A., \& Sanhudo, C. E. D. (2011). Taxonomia e Filogenia das Formigas-Cortadeiras. In T. M. C. Della Lucia (Ed.), Formigas Cortadeiras-Da Biologia ao Manejo (pp. 27-48). Viçosa: Ed. UFV.

Caldeira, M. A., Zanetti, R., Moraes, J. C., \& Zanuncio, J. C. (2005). Distribuição espacial de sauveiros (Hymenoptera: Formicidae) em eucaliptais. Cerne, 11, 34-39.

Costa, E. C., D’avila, M., \& Cantarelli, E. B. (2014). Entomologia florestal (3rd ed.). Santa Maria: Editora da UFSM.

Davis, P. M. (1993). Statistics for describing populations. In L. Pedigo, \& G. D. Buntin (Eds.), Handbook of sampling methods for arthropods in agriculture (pp. 33-54). Boca Raton: CRC Press.

Della Lucia, T. M., Gandra, L. C., \& Guedes, R. N. (2014). Managing Leaf-Cutting Ants: Peculiarities, Trends and Challenges. Pest. Management Science, 70, 14-23. https://doi.org/10.1002/ps.3660

FAMATO (Federação da Agricultura e Pecuária do Estado de Mato Grosso). (2013). Diagnóstico de Florestas Plantadas do Estado de Mato Grosso. Cuiabá: Instituto Mato-Grossense de Economia Agropecuária. Retrieved September 6, 2018, from http://imea.com.br/upload/Relatorio_final_floresta_plantada.pdf

Hernández, J. V., \& Jaffé, K. (1995). Dano econômico causado por populações de formigas Atta laevigata (F. Smith) em plantações de Pinus caribaea Mor. e elementos para o manejo da praga. Anais da Sociedade Entomológica do Brasil, 24, 287-298.

Lasmar, O., Zanetti, R., Santos, A., \& Fernandes, B. V. (2012). Use of Geostatistics to determine the spatial distribution and infestation rate of leaf-cutting ant nests (Hymenoptera: Formicidae) in Eucalyptus plantations. Neotropical Entomology, 41, 324-332. https://doi.org/10.1007/s13744-012-0040-1

Morisita, M. (1962). Is index, a measure of dispersion of individuals. Journal: Researches on Population Ecology, 4, 1-7.

Morisita, M. (1959). Measuring of the dispersion of individuals and analysis of the distributional patterns. Memoirs of the Faculty of Science, 2, 215-235.

Nickele, M. A., Reis Filho, W., Oliveira, E. B. de, \& Iede, E. T. (2009). Densidade e tamanho de formigueiros de Acromyrmex crassispinus em plantios de Pinus taeda. Pesquisa Agropecuária Brasileira, 44, $347-353$. https://doi.org/10.1590/S0100-204X2009000400003

Nickele, M. A., Oliveira, E. B. de, Reis Filho, W., Iede, E. T., \& Ribeiro Rodrigo, D. (2010). Distribuição Espacial de Formigueiros de Acromyrmex crassispinus (Forel) (Hymenoptera: Formicidae) em Plantios de Pinus taeda. Neotropical Entomology, 39, 862-872. https://doi.org/10.1590/S1519-566X2010000600003

Ramos, V. M., Forti, L. C., Andrade, A. P. P., Noronha, N. C., \& Silva Camargo, R. S. (2008). Density and spatial distribution of Atta sexdens rubropilosa and Atta laevigata colonies (Hym., Formicidae) in Eucalyptus spp. Forests. Sociobiology, 51, 775-781.

Roglin, A., Sousa, N. J., Pinto, J. R. R., Koehler, H. S., \& Ferronato, M. Z. (2013). Identificação e quantificação de formigas cortadeiras em áreas degradadas em processos de recuperação. Enciclopédia Biosfera, 9 , 1260-1269.

Silva, L. H., \& Ukan, D. (2015). Distribuição espacial de formigas cortadeiras em um plantio florestal de Eucalyptus benthamii, no Município de Irati-PR. Enciclopédia Biosfera, 11, 1456-1463. https://doi.org/ 10.18677/Enciclopedia_Biosfera_2015_174

Souza, R. M., Anjos, N., Cordeiro, G., \& Mourão, S. A. (2009). Primeiro registro de Atta sexdens rubropilosa Forel atacando árvores de nim, Azadirachta indica a. juss. Arquivos do Instituto Biológico, 76, 729-733. 
Zanetti, R., Jaffé, K., Vilela, E. F., Zanuncio, J. C., \& Leite Hélio, G. (2000). Efeito da densidade e do tamanho de sauveiros sobre a produção de madeira em eucaliptais. Anais da Sociedade Entomológica do Brasil, 29, 105-112. https://doi.org/10.1590/S0301-80592000000100013

Zanetti, R., Zanuncio, J. C., Mayhé-Nunes, A. J., Medeiros, A. G. B., \& Souza-Silva, A. (2003). Combate sistemático de formigas-cortadeiras com iscas granuladas, em eucaliptais com cultivo mínimo. Revista Árvore, 27, 387-392. https://doi.org/10.1590/S0100-67622003000300016

Zanetti, R., Souza, A., \& Calegario, N. (2011). Nível de dano econômico para formigas-cortadeiras em função do índice de produtividade florestal de eucaliptais em uma região de Mata Atlântica. Neotropical. Entomology, 40, 483-488.

Zanuncio, J. C., Lopes, T. E., Zanetti, R., \& Couto, L. (2002). Spatial distribution of nests of the leaf-cutting ant Atta sexdens rubropilosa (Hymenoptera: Formicidae) in plantations of Eucalyptus urophylla in Brazil. Sociobiology, 39, 231-242.

\section{Copyrights}

Copyright for this article is retained by the author(s), with first publication rights granted to the journal.

This is an open-access article distributed under the terms and conditions of the Creative Commons Attribution license (http://creativecommons.org/licenses/by/4.0/). 